\title{
Antibody response of channel catfish after channel catfish virus infection and following dexamethasone treatment
}

\author{
Ana B. Arnizaut, Larry A. Hanson* \\ Department of Basic Sciences, College of Veterinary Medicine, Mississippi State University, Mississippi 39762, USA
}

\begin{abstract}
Channel catfish virus (CCV, Ictalurid herpesvirus 1) and CCV disease have been extensively studied. Yet, little is known about CCV-host interaction after resolution of the primary infection. In order to determine potential recrudescence of CCV from latency, we established latency by exposing channel catfish juveniles with CCV or a thymidine kinase-negative recombinant (CCVlacZ) at a dose that caused less than $20 \%$ mortality. Then, we evaluated antibody response by serially sampling the same fish at 0 (pre-infection), 30,60 and $90 \mathrm{~d}$ post challenge (DPC). We then attempted to induce viral recrudescence by intramuscular administration of dexamethasone and sampled the fish at $2,4,7$, or $10 \mathrm{~d}$ post treatment. Recrudescence was evaluated by leukocyte co-cultivation and cell culture of tissue homogenates but no virus was detected. Western blot data demonstrated the highest number of seropositive fish by 30 DPC and a secondary antibody induction after dexamethasone treatment. The antigen specificity of the secondary response corresponded to viral proteins with molecular masses similar to those recognized by the same fish by $30 \mathrm{DPC}$. The recognized proteins were predominantly large, ranging from $\sim 90$ to $>200 \mathrm{kDa}$. Expression analysis of selected virus genes at 90 DPC and following dexamethasone treatment demonstrated occasional immediate-early virus gene expression in peripheral blood leukocytes. Early and late gene expression was rarely detected. The combined data suggest restricted re-activation of CCV in our experimental system. Primary and secondary responses and virus gene expression were demonstrated in CCVlacZ-exposed fish but were less frequent than in CCV-exposed fish.
\end{abstract}

KEY WORDS: Ictalurus punctatus $\cdot$ Teleost $\cdot$ Ictalurid herpesvirus $1 \cdot$ Alloherpesviridae $\cdot$ Herpesvirus latency · Thymidine kinase-negative recombinant · Viral gene expression · Neutralizing antibody

\section{INTRODUCTION}

Channel catfish virus (CCV), also known as Ictalurid herpesvirus 1, is the causative agent of a severe hemorrhagic disease frequently associated with high mortality in channel catfish Ictalurus punctatus fry and fingerlings (Fijan et al. 1970). Survivors of CCV primary infection become latently infected and constitute potential carriers for vertical and horizontal transmission. Herpesvirus latency is characterized by the absence of lytic viral proteins and productive virions on infected host cells. Neither the latency site nor latencyassociated transcripts have yet been identified for
CCV. However, CCV DNA has been detected in several tissues including muscle, fins, anterior and posterior kidneys, spleen, gonads, brain, intestine and peripheral blood leukocytes (PBL) from asymptomatic carriers (Wise \& Boyle 1985, Gray et al. 1999).

Although CCV is phylogenetically distant from herpesviruses of mammals and birds, many of its biological properties are similar to alphaherpesviruses. Recently, the taxonomy of herpesvirus has been updated with the incorporation of the genus Ictalurivirus into the new family Alloherpesviridae (Davison et al. 2009). The initial productive phase of infection of the most extensively studied alphaherpesvirus, herpes sim- 
plex type 1 (HSV-1, Human herpesvirus 1), is characterized by expression of immediate-early (IE), early (E), and late (L) classes of viral genes in an ordered lytic cascade that culminates in the replication and packaging of viral DNA into infectious particles, and eventual lysis of the infected cells (Honess \& Roizman 1974). With respect to the kinetics of gene expression, Dixon \& Farber (1980) observed similar cascade regulation of the synthesis of 3 distinct classes of $\mathrm{CCV}$ proteins.

Basic components of the morphology, biology, and genomic structure of CCV (Wolf \& Darlington 1971, Plumb \& Gaines 1975, Chousterman et al. 1979, Davison 1992) have been characterized since this fish herpesvirus was first isolated by Fijan (1968). CCV encodes thymidine kinase (TK), which phosphorylates thymidine and other deoxynucleotides and analogs (Hanson \& Thune 1993). For HSV-1, TK is not required for growth in cell culture but is essential for virulence (Jamieson et al. 1974, Field \& Wildy 1978, Efstathiou et al. 1989) and reactivation from latency (Tenser \& Dunstan 1979). A potential live recombinant vaccine vector with a deletion in the TK gene of CCV was able to induce protective immunity and a humoral immune response to the expressed foreign gene product (Zhang \& Hanson 1995, 1996). However, to be a viable candidate as a live virus vaccine, it is necessary to characterize the ability of this virus to spread, to establish, and to reactivate from latency.

Little is known about the molecular process that controls CCV latency and reactivation nor the role played by the immune system in controlling reactivated infection. We do know latently infected fry are common in catfish hatcheries and in fingerling ponds. In a survey of major hatcheries, latent CCV infection was prevalent and the infection was assumed to be due to vertical transmission since no virus could be cultured from the populations and no CCV disease (CCVD) occurred (Thompson et al. 2005). Also primary exposure to CCV appears to more frequently result in a latent carrier state than a lethal form of disease. In field studies, population prevalence of CCV latency increased over time with no overt disease (Thompson et al. 2005) and in experimental challenges, exposure to low levels of virus resulted in disseminated virus replication but low mortality (Kancharla \& Hanson 1996). Since reactivation is a complex phenomenon that is infrequent unless an appropriate stimulus is applied, evaluation of the expression of RNA necessary for activation of the lytic cascade and production of infectious particles should be more sensitive during the early events of reactivation than culture. In reactivation studies with herpesviruses of mammals, detection of virus gene expression and increases in virus DNA are often more sensitive indicators than virus isolation in cell culture (Baxi et al. 1996, Bevan et al. 1996).
The objectives of this study were to establish an experimental model to study latency and recrudescence of CCV in its natural host and to evaluate the host-pathogen interaction in this process. We were not successful in inducing overt recrudescence, but we found an increase in CCV DNA derived from caudal fin samples of latently infected channel catfish $7 \mathrm{~d}$ post dexamethasone (DEX) treatment without reactivation of culturable virus. Therefore, we investigated additional indicators of reactivation, namely a rise of anti$\mathrm{CCV}$ antibody responses and the expression of selected viral genes in fish that had been exposed to $\mathrm{CCV}$ or a less virulent TK-negative recombinant of the virus and injected with DEX.

\section{MATERIALS AND METHODS}

Viruses, fish, and cell lysates. CCV (strain Auburn 1 Clone A, American Type Culture Collection no. VR$665)$ and the TK-negative recombinant CCV containing the lacZ gene replacing both TK loci in the genome (CCVlacZ) (Zhang \& Hanson 1995, 1996) were propagated in channel catfish ovary cells (CCO) as previously described (Hanson et al. 1994). Virus stocks were quantified in a plaque assay on CCO cells using the method of Buck \& Loh (1985). Research fish were hatched and reared indoors, measured $\sim 15 \mathrm{~cm}$ in length, and had no previous history of CCVD. Cell lysates for western blots were produced by infecting confluent brown bullhead (BB) cells with 0.5 plaque forming units (PFU) $\mathrm{CCV}$ cell ${ }^{-1}$. The infected cell cultures were maintained in serum-free Dulbecco's modified Eagle's medium (DMEM, Sigma-Aldrich) supplemented with $25 \mathrm{mM}$ HEPES, $200 \mathrm{IU} \mathrm{ml}^{-1}$ penicillin, and $200 \mathrm{\mu g} \mathrm{ml}^{-1}$ streptomycin (GIBCO BRL). After $\sim 12 \mathrm{~h}$ of incubation at $30^{\circ} \mathrm{C}, \mathrm{CCV}$ and mock-infected $\mathrm{BB}$ cell monolayers were harvested and centrifuged at $700 \times g$ for $10 \mathrm{~min}$ at $4^{\circ} \mathrm{C}$. Pellets were resuspended in phosphate-buffered saline (PBS) $\left(8 \mathrm{mM} \mathrm{Na}_{2} \mathrm{HPO}_{4}, 2 \mathrm{mM}\right.$ $\mathrm{KH}_{2} \mathrm{PO}_{4}, 138 \mathrm{mM} \mathrm{NaCl}, 3 \mathrm{mM} \mathrm{KCl}, \mathrm{pH}$ 7.4), aliquoted, and stored at $-80^{\circ} \mathrm{C}$.

Experimental protocol. All work with channel catfish was registered and done under the supervision of Mississippi State University Institutional Animal Care and Use Committee using approved protocols to assure humane handling and use. Fish were anesthetized by immersion exposure to tricaine methane sulfonate (MS222, Argent Chemical Laboratories) prior to injection, bleeding or caudal fin sampling.

Evaluation of dexamethasone and heat stress as inducers of recrudescence. To evaluate a method to induce consistent viral recrudescence, 60 channel catfish fingerlings, $\sim 7 \mathrm{~cm}$ in length, from a CCV-positive spawn of latently infected broodfish (identified by 
positive results using CCV-specific PCR), were distributed into 4 tanks ( $\mathrm{N}=15$ fish per treatment group). To monitor the presence of infectious virus, posterior kidney homogenates of 10 additional fish that originated from the same rearing tank were cultured for virus. The caudal fins of all experimental fish were biopsied for CCV DNA analyses by PCR. Then 2 control treatment groups were injected intramuscularly with either PBS (control) or DEX (Dexaject, Phoenix Scientific) at $0.55 \mathrm{mg} \mathrm{kg}^{-1}$ body weight, and the water temperature was kept constant at $30^{\circ} \mathrm{C}$. The other 2 groups received a PBS or DEX injection ( $0.55 \mathrm{mg} \mathrm{kg}^{-1}$ body weight), but the water temperature was increased to $36^{\circ} \mathrm{C}$ for $3 \mathrm{~h}$ and returned to $30^{\circ} \mathrm{C}$. We used this dose of DEX because Bowser et al. (1985) had shown it to be effective in inducing CCV recrudescence. At $7 \mathrm{~d}$ post treatment (DPT), all fish were euthanized, posterior kidneys were cultured for infectious virus and caudal fins were sampled for CCV DNA analyses by PCR.

Evaluation of experimental latent infections and DEX induced recrudescence. A total of $110 \mathrm{CCV}$-negative channel catfish (mean weight $=82 \mathrm{~g}$; the fish used were obtained from an isolated population with no history of CCVD, produced and cultured in specific pathogen-free conditions and CCV status was confirmed by PCR on caudal fin clips and PBL) was distributed into 22 tanks ( $\mathrm{N}=5$ fish per tank). To identify each fish, we used a body mark system that consisted of a combination of caudal fin and barbel clips. Fish were mock-infected (controls, $\mathrm{N}=20$ ) or immersion challenged with $3 \times 10^{5} \mathrm{PFU}$ of CCV $(\mathrm{N}=40)$ or CCVlacZ ( $\mathrm{N}$ =50) per $10 \mathrm{ltank}$ for $30 \mathrm{~min}$ at $30^{\circ} \mathrm{C}$. This dose and challenge method was used because it had previously been shown to result in a low level of mortality and a high percentage of infection (Hanson et al. 2004). Fish from each challenge tank were then transferred to a respective $80 \mathrm{l}$ aerated, flow-through tank held at $30^{\circ} \mathrm{C}$ with $12 \mathrm{~h}$ light: $12 \mathrm{~h}$ dark cycle and fed $32 \%$ commercial catfish feed ad libitum once daily. Fish were bled by caudal vein puncture. Serum samples were harvested at $0,30,60$, and $90 \mathrm{DPC}$, heat inactivated at $45^{\circ} \mathrm{C}$ for 30 min and stored at $-20^{\circ} \mathrm{C}$ until screened by western blot assays. At 90 DPC, a subgroup of 15 mock-infected, 33 CCVlacZ- and 23 CCV-exposed fish were treated with a single intramuscular injection of DEX at $0.55 \mathrm{mg} \mathrm{kg}^{-1}$ body weight. Control groups included 10 CCVlacZand $7 \mathrm{CCV}$-exposed fish that received a single intramuscular injection of PBS. Subsamples of these groups were taken at 2, 4, 7, and 10 DPT, and evaluated for $\mathrm{CCV}$ production, viral gene expression and specific antibody response against CCV antigens.

Polymerase chain reaction. PCR was performed and products were evaluated as previously described (Thompson et al. 2005) with the following modifications. Each PCR used $50 \mu$ l of reaction mixture, $5 \mathrm{ng}$ of
DNA template and cycling conditions of 1 cycle of $94^{\circ} \mathrm{C}$ for $10 \mathrm{~min}, 45$ serial cycles of $93^{\circ} \mathrm{C}$ for $30 \mathrm{~s}, 60^{\circ} \mathrm{C}$ for $30 \mathrm{~s}$, and $72^{\circ} \mathrm{C}$ for $1 \mathrm{~min}$ followed by 1 cycle of $72^{\circ} \mathrm{C}$ for $5 \mathrm{~min}$. Tissue culture-grade water (Sigma-Aldrich) was used for the negative control and $5 \mathrm{pg}$ of purified CCV DNA served as positive control. DNA sample concentrations were determined by a Gene Spec I (Hitachi Genetic Systems) spectrophotometer.

Western blot analysis. Mock- and CCV-infected BB cell lysates were diluted (vol/vol) in a modified Laemmli sample buffer (Bio-Rad Laboratories), disrupted by boiling for $5 \mathrm{~min}$, and centrifuged at $18000 \times$ $g$ for 3 min (Laemmli 1970). Electrophoresis was performed using $12 \%$ sodium dodecyl sulfate polyacrylamide gel electrophoresis (SDS-PAGE) Tris-HCl gels in a Mini-gel unit (Bio-Rad) using $1.5 \mathrm{~mm}$ thick spacers and preparative gel combs. Electrophoresis was carried out at $100 \mathrm{~V}$ for the stacking gel and $200 \mathrm{~V}$ for the SDS-PAGE for $\sim 40 \mathrm{~min}$. Prestained SDS-PAGE broad range standards (Bio-Rad) and ECL protein standards (Amersham Pharmacia Biotech) were used as molecular weight markers. Separated proteins were visualized by incubating gels for $1 \mathrm{~h}$ with agitation with GelCode ${ }^{\circledR}$ blue stain reagent (Pierce) and destaining with distilled water. For the western blot analysis (Towbin et al. 1979, Burnette 1981), proteins were electroblotted onto nitrocellulose membranes $(0.2 \mu \mathrm{m}, 7 \times 8.4 \mathrm{~cm}$, Bio-Rad) using a Mini trans-blot apparatus (Bio-Rad) for $1 \mathrm{~h}$ at $100 \mathrm{~V}$. Blotted proteins were visualized by adding $0.5 \%$ Ponceau S solution (Sigma-Aldrich) in acetic acid and subsequently destained with PBS. Blots were soaked overnight at $4^{\circ} \mathrm{C}$ in blocking buffer containing 5\% non-fat dry milk (Johnson et al. 1984) in Tris-buffered saline (TBS) (10 mM Tris-HCl, $150 \mathrm{mM}$ $\mathrm{NaCl}, \mathrm{pH}$ 7.4). Blots were transferred to a Mini-protean II multiscreen apparatus (Bio-Rad) and were incubated overnight at $4^{\circ} \mathrm{C}$ with $25 \mu$ of fish serum samples diluted 1:50 in half-strength blocking buffer under agitation. Negative control serum was obtained from a broodfish that had previously tested negative for CCV DNA by PCR and had a negative titer in a serum neutralization assay. Positive control serum was obtained by bleeding a juvenile catfish $21 \mathrm{~d}$ post immunization with a single intraperitoneal injection of $1 \times 10^{5} \mathrm{PFU}$ of CCV. After washing 4 times with $0.2 \%$ Tween 20 (BioRad) in TBS, blots were incubated at room temperature for $2 \mathrm{~h}$ with $8 \mathrm{ml}$ of the hybridoma supernatant from mouse anti-channel catfish IgM monoclonal 9E1 (Lobb \& Clem 1982, Lobb et al. 1984) diluted 1:4 in halfstrength blocking buffer. Following another series of washing steps with $0.2 \%$ Tween 20 in TBS, blots were incubated at room temperature for $1 \mathrm{~h}$ with goat anti-mouse immunoglobulins conjugated to horseradish peroxidase (Southern Biotechnology Associates) diluted 1:1500 in half-strength blocking buffer. After 4 
washing steps as described above and 2 rinses with TBS, labeling was detected using the ECL chemiluminescence kit (Amersham) and hyperfilm ECL (Amersham) as described by the manufacturer.

Serum neutralization index test (SNI). The SNI was performed similarly to the protocol described by Crawford et al. (1999) with few modifications. Heat-inactivated fish serum samples collected at $60 \mathrm{DPC}$ and after DEX treatment were diluted 1:25 in serum-free DMEM supplemented with $25 \mathrm{mM}$ HEPES, $200 \mathrm{IU} \mathrm{ml}^{-1}$ penicillin, and $200 \mu \mathrm{g} \mathrm{ml}^{-1}$ streptomycin (diluent medium). The stock of CCV was serially diluted 10-fold with diluent medium, and $200 \mu \mathrm{l}$ of each virus dilution was distributed into 7 replicates of 96-well microtiter plates (Corning, Fisher Scientific). Approximately $200 \mu \mathrm{l}$ of diluted fish serum was added to each of 7 replicate wells containing respective virus dilution. Control wells received virus dilutions and diluent medium. After incubation for $1 \mathrm{~h}$ at $30^{\circ} \mathrm{C}, 50 \mu \mathrm{l}$ of $\mathrm{CCO}$ cell suspension containing $\sim 3 \times 10^{6}$ cells were added to each microtiter plate well. The plates were incubated for $5 \mathrm{~d}$ at $30^{\circ} \mathrm{C}$ and observed daily for plaque formation. The virus titers were determined on the basis of the $50 \%$ tissue culture infectious dose reduction point $\left(\mathrm{TCID}_{50}\right)$ and calculated by the method of Reed \& Muench (1938). The neutralization index produced by each fish serum sample was expressed as the difference in $\log _{10}\left(\mathrm{TCID}_{50} \mathrm{ml}^{-1}\right)$ between the virus dilutions incubated with diluent medium (control wells) and virus dilutions in the presence of fish serum samples. SNI values by treatment were examined using an unbalanced 1 -way analysis of variance $(\alpha=0.05)$ (SAS 1990). In addition, to test the null hypothesis of no differences between the sample means (i.e. treatments) an unpaired $t$-test (Steel \& Torrie 1980) with a test of approximation for unequal variances was used. The Type I error probability was set at $\alpha=0.05$. Comparisons of SNI values to western blot results were made using Spearman's correlation analyses.

Peripheral blood leukocyte isolation and co-cultivation with CCO cells. PBL were isolated from $150 \mu \mathrm{l}$ of whole blood containing EDTA, overlaid onto $500 \mu \mathrm{l}$ of Histopaque 1077 (Sigma-Aldrich), and centrifuged at $500 \times g$ for $10 \mathrm{~min}$ at room temperature. The buffy coat layer containing PBL was collected, suspended in Hanks' balanced salt solution, calcium-magnesium free (HBSS-CMF) (GIBCO BRL), at osmolarity $272(\mathrm{pH}$ 7.3), and centrifuged at $500 \times g$ for $5 \mathrm{~min}$. The pellet was resuspended in $500 \mu \mathrm{l}$ of HBSS-CMF. Total DNA was extracted from $100 \mu \mathrm{l}$ of PBL suspension and analyzed by PCR. The remaining $400 \mu \mathrm{l}$ of PBL suspension were cultured in separate wells of a 6 -well tissue culture plate containing $70 \%$ confluent $\mathrm{CCO}$ cell monolayers. Tissue cultures were maintained at $30^{\circ} \mathrm{C}$ in DMEM (without sodium bicarbonate) supplemented with $10 \%$ fetal calf serum and 25 mM HEPES, and observed daily for $10 \mathrm{~d}$ for cytopathic effect (CPE) as previously described by Kancharla \& Hanson (1996). They were then blind-passaged by transferring supernatant fluids to a new plate of $\mathrm{CCO}$ cells at $70 \%$ confluency. After observation for $10 \mathrm{~d}$ without CPE, each tissue culture was subsequently blind-passaged 2 consecutive times by trypsinizing and transferring $50 \%$ of the $\mathrm{CCO}$ cell suspension to a new 6 -well tissue culture plate.

Isolation of nucleic acids from PBL and caudal fin samples. Caudal fin clips and PBL were chosen as a non-invasive sampling method for PCR and gene expression analyses in live fish. Approximately 50 to $100 \mathrm{mg}$ of caudal fin tissue and $100 \mu \mathrm{l}$ of PBL suspension were collected and transferred to RNAlater tissue storage reagent with RNA stabilization solution (Ambion) at $-20^{\circ} \mathrm{C}$. Total RNA was extracted using TRIzol isolation reagent (GIBCO BRL) following the manufacturer's protocol. The air-dried RNA pellet was dissolved in $50 \mu \mathrm{l}$ of DEPC (diethyl pyrocarbonate)treated RNase- and DNase-free water (Ambion) and analyzed by RT-PCR. During the evaluation of a method to induce consistent viral recrudescence, total DNA was isolated from caudal fin samples by the Puregene DNA isolation kit (Gentra Systems) according to the manufacturer's protocol and analyzed by PCR.

RT-PCR. First-strand cDNA synthesis was performed with $\sim 0.6 \mu \mathrm{g}$ of total RNA sample in $10 \mu \mathrm{l}$ reactions as described by Chen et al. (2002). Samples were diluted in $40 \mu \mathrm{l}$ of DEPC RNase- and DNase-free water and stored at $-20^{\circ} \mathrm{C}$. The PCR reaction was performed in a $50 \mu \mathrm{l}$ volume containing $20 \mathrm{pmol}$ of each primer, $2.5 \mathrm{mM}$ of each deoxynucleoside triphosphate, $25 \mathrm{mM}$ of $\mathrm{MgCl}_{2}$, and 1.5 units of AmpliTaq Gold DNA polymerase (PE Biosystems) with $5 \mu \mathrm{l}$ of cDNA template. Specific PCR primer pairs were designed based on available sequences (GenBank accession no. NC_ 001493; Davison 1992) for open reading frame (ORF) 3 , ORF 12, ORF 57, and ORF 46 regions of CCV, and are listed in Table 1. Cycling reactions were performed using an Omn-E thermal cycler (HyBaid, Pegasus Scientific). After a single cycle of $10 \mathrm{~min}$ at $94^{\circ} \mathrm{C}, 35$ amplification cycles were performed, each consisting of $30 \mathrm{~s}$ at $93^{\circ} \mathrm{C}, 30 \mathrm{~s}$ at $56^{\circ} \mathrm{C}$, and $1 \mathrm{~min}$ at $72^{\circ} \mathrm{C}$, followed by a final cycle of $5 \mathrm{~min}$ at $72^{\circ} \mathrm{C}$. Negative controls included tissue culture water (Sigma-Aldrich) and samples processed without reverse transcriptase. Purified CCV DNA (5 pg) served as positive control. To monitor the expression of the cellular housekeeping gene $\beta$-actin in fish samples, PCR was performed using actin primers as described (Chen et al. 2002).

Kinetics of CCV gene expression in vitro. To evaluate RT-PCR for the expression of IE, E, and L CCV genes, infected $\mathrm{CCO}$ cells were analyzed at various times post CCV inoculation with or without $100 \mu \mathrm{g} \mathrm{ml}^{-1}$ 
of cycloheximide (Sigma-Aldrich). Tissue culture flasks containing $70 \%$ confluent monolayers of $\mathrm{CCO}$ cells were inoculated with CCV at a multiplicity of infection of $10 \mathrm{PFU}$ cell $^{-1}$. After incubation for $40 \mathrm{~min}$ at $30^{\circ} \mathrm{C}$, cell monolayers were harvested at 0,1 , and $3 \mathrm{~h}$ post infection, and total RNA was extracted from cell lysates. RT-PCR was used to monitor expression of IE, E and L CCV genes.

Slot-blot hybridization. An oligonucleotide probe (5'-CCG GAC CGA TGT ACA CGT GTG-3') was designed on the basis of an available sequence (Davison 1992) from the ORF 3 region of the CCV genome. The BrightStar psoralen-biotin nonisotopic labeling kit (Ambion) was used to biotinylate $500 \mathrm{ng}$ of the probe according to the manufacturer's instructions. For the slot-blot hybridization, $10 \mu \mathrm{l}$ of PCR products amplified by ORF 3 -specific primers were diluted with $140 \mu \mathrm{l}$ of Tris-ethylenediaminetetraacetic acid buffer $(\mathrm{pH}$ 8.0) and mixed with $150 \mu \mathrm{l}$ of denaturing buffer $(0.4 \mathrm{M}$ $\mathrm{NaOH}, 10 \mathrm{mM}$ EDTA). Positive and negative controls included PCR products amplified from purified CCV DNA and $\beta$-actin, respectively. The mixture was placed in a water bath for $10 \mathrm{~min}$ and centrifuged at $7000 \times g$ for $5 \mathrm{~s}$. The cDNA samples were chilled on ice, applied to Zeta-probe GT genomic membranes (Bio-Rad) and immobilized on the membrane by adding $500 \mu \mathrm{l}$ of $0.4 \mathrm{M} \mathrm{NaOH}$ to each well of the slotblot apparatus. Upon removal from the manifold system, membranes were washed in $2 \times$ SSC $(20 \times$ salinesodium citrate concentrate stock contained $3 \mathrm{M} \mathrm{NaCl}$, $0.3 \mathrm{M}$ trisodium citrate, $\mathrm{pH}$ 7.0), and air-dried overnight at room temperature. After pre-hybridization for 30 min at $42^{\circ} \mathrm{C}$ with hybridization buffer containing ECL hybridization buffer component, $20 \times$ SSC, $10 \%$ SDS, and ECL liquid block, the membrane was hybridized for $\sim 17 \mathrm{~h}$ with $20 \mu \mathrm{l}$ of biotinylated probe at a final concentration of $10 \mathrm{ng} \mathrm{ml}^{-1}$. The membrane was washed twice, initially with $5 \times \mathrm{SSC}$ and $0.1 \% \mathrm{SDS}$ at

Table 1. Primer pairs used in RT-PCR for channel catfish virus (CCV) immediateearly (IE), early (E), and late (L) gene expression, and the housekeeping gene $\beta$-actin

\begin{tabular}{|c|c|c|c|}
\hline Primers & $\begin{array}{l}\text { Gene } \\
\text { class }\end{array}$ & Sequence $\left(5^{\prime}-3^{\prime}\right)$ & $\begin{array}{l}\text { Product } \\
\text { size (bp) }\end{array}$ \\
\hline CCVORF3.5011U20 & IE & GAC GAT GAG GGC GAC GAC AC & 150 \\
\hline CCVORF3.5144L17 & IE & GGC TGG CGG GTG AGT CC & \\
\hline CCVORF1215775U19 & IE & GGA GTC CCT CTT CGG TCA C & 147 \\
\hline CCVORF1215905L17 & IE & CTG ATC CCG GTC ACC AG & \\
\hline CCVORF5775758U18 & $\mathrm{E}$ & AGT CAT GGC GAC GGA TTA & 155 \\
\hline CCVORF5775894L19 & E & TGG GGT ACA TGC TGG TAA A & \\
\hline CCVORF46.55453U20 & $\mathrm{L}$ & CGC GTT GGT ACT GGT TGG TA & 148 \\
\hline CCVORF46.55582L19 & $\mathrm{L}$ & GTT TCG GGG AAT GGT TGA A & \\
\hline ACTIN2458L19 & & TCG TAG ATG GGC ACA GTG T & 161 \\
\hline ACTIN2013U18 & & GCC AAC AGG GAA AAG ATG & \\
\hline
\end{tabular}

room temperature for 5 min and subsequently with $1 \times$ $\mathrm{SSC}$ and $0.1 \% \mathrm{SDS}$ at $59^{\circ} \mathrm{C}$ for $15 \mathrm{~min}$. The hybridization signal was detected using the BrightStar BioDetect nonisotopic detection system (Ambion) following the recommendations of the manufacturer. The membrane was wrapped in a single layer of plastic wrap, stored in the dark for $24 \mathrm{~h}$, and exposed to hyperfilm ECL (Amersham) for $\sim 10 \mathrm{~min}$.

\section{RESULTS}

\section{Evaluation of dexamethasone and heat stress as inducers of recrudescence}

To evaluate conditions that induce CCV recrudescence, we treated carrier fish with DEX, elevated temperature or with both, then evaluated the fish for the presence of infectious virus and compared CCV DNA content by PCR. By Day 7 post treatment, we were not able to detect infectious virus in any of the posterior kidney samples $(\mathrm{N}=70)$, even after performing 3 blind passages. However, the percentage of fish testing positive for CCV DNA by PCR increased from 40 to $100 \%$ in the group treated with DEX but not heat stress (Fig. 1). Such an increase was not observed in any other treatments. This suggested that some recrudescence was occurring in the DEX-treated fish. Therefore, we used this method in a more in-depth analysis of recrudescence which included viral gene expression and the antibody response of the host.

\section{Evaluation of experimental latent infections and DEX induced recrudescence}

In the second study, individually identified fish that were mock-infected or challenged with $\mathrm{CCV}$ or CCVlacZ were evaluated for changes in anti-CCV antibodies by serially sampling the same fish over 90 DPC. Then at $90 \mathrm{DPC}$, we attempted to induce viral recrudescence using DEX, and subsamples were evaluated at $2,4,7$, and 10 DPT for changes in anti-CCV antibodies, infectious virus production and virus gene expression. At 4 DPC, 1 fish each died in the CCV and CCVlacZ treatment groups. Both dead fish demonstrated clinical signs of CCVD, and CCO cultures inoculated with kidney homogenates from these fish exhibited characteristic CPE. At 90 DPC, no productive virus was recovered from any of the PBL 


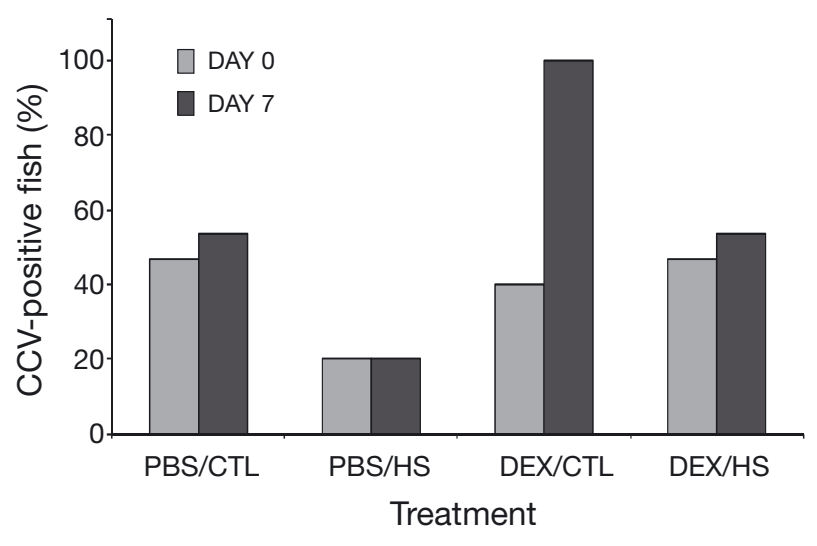

Fig. 1. Ictalurus punctatus. Percentage of fish testing positive for channel catfish virus (CCV) DNA at 0 and $7 \mathrm{~d}$ following attempted reactivation treatment with dexamethasone (DEX, $0.55 \mathrm{mg} \mathrm{kg}^{-1}$ body weight) or phosphate buffered saline (PBS; control). In addition to the treatment, fish were either exposed to heat stress (HS) or not (CTL). DNA was detected in caudal fin clips using PCR. N = 15 fish per treatment group

cultures. After terminal sampling of DEX and PBS control treated fish, no virus was recovered from PBL co-culture or from $\mathrm{CCO}$ cultures of kidney tissue homogenates.
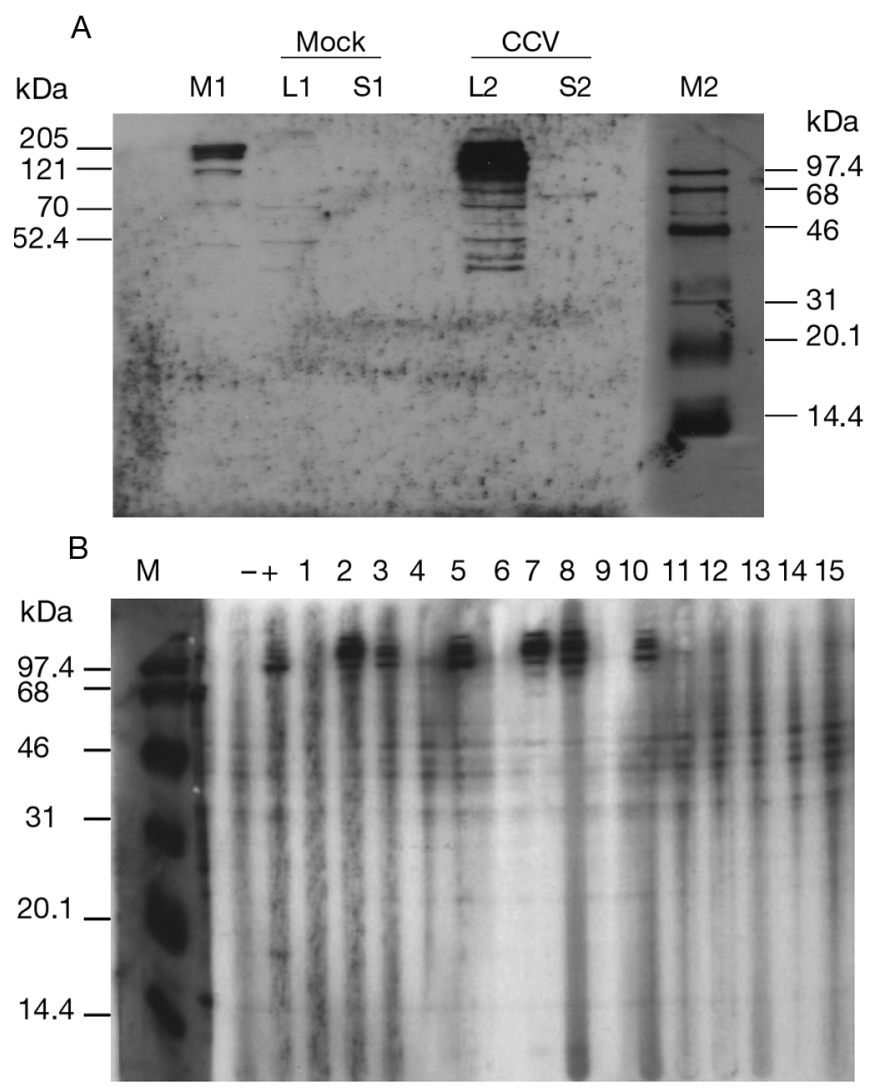

Sampling time: 0306090 PT 0306090 PT 0306090 PT Fish no. $21 \mathrm{E}$

\section{Western blot analysis of seroconversion}

Western blot analysis of CCV-infected BB cells with serum from CCV-infected fish demonstrated antibody recognition of multiple CCV-specific proteins. Fig. 2A demonstrates the protein profile of mock- and CCV-infected BB cell lysates and cell supernatants using a positive control serum from a juvenile catfish immunized with a single intraperitoneal injection of $1 \times 10^{5} \mathrm{PFU}$ of CCV. We used this assay to evaluate the change in response of $\mathrm{CCV}$ and CCVlacZ-exposed fish over time and after exposure to DEX. Western blot analyses revealed the immune response profile of each fish (Fig. 2B). Seroconversion occurred by 30 DPC in 17 of 22 (77.3\%) CCV-exposed fish. Out of 22 CCVlacZ-exposed fish, only $2(9.1 \%)$ produced a specific antibody response by the same time post challenge. These levels dwindled to $4.5 \%$ and $0 \%$ for CCV- and CCVlacZexposed fish by $90 \mathrm{DPC}$, respectively. Secondary induction of the antibody response was demonstrated in 10 of $22(45.5 \%)$ CCV-exposed fish compared to 3 of $22(13.6 \%)$ CCVlacZ-exposed fish after injection with either DEX or PBS, with the strongest induction occurring in the CCV-exposed fish that were treated with DEX (Fig. 3). The most prominent antibody reactivity was present in serum samples from CCV exposed fish and was directed against viral proteins with molecular masses ranging from $\sim 90$ to $>200 \mathrm{kDa}$ (Fig. 2B, Table 2). In 9 out of 14 CCV-exposed fish, the secondary induction of an antibody response coincided with the reappearance of at least 1 protein with molecular mass similar to that present at 30 DPC (Table 2). No secondary immune response was observed when fish were treated with PBS alone. Out of 48 fish screened, 2 (3C and 18E) had antibodies to $\mathrm{CCV}$ antigens prior to the experimental

Fig. 2. Western blot analysis of mock- and channel catfish virus (CCV)-infected brown bullhead (BB) cell lysates using catfish serum. Cell lysates and supernatants were separated by $12 \%$ SDS-PAGE and blotted onto nitrocellulose membranes. (A) Positive control catfish serum against mockinfected cell lysates (L1) and supernatants (S1) or aganist CCV-infected cell lysates (L2) and supernatants (S2). Markers are Bio-Rad Prestained SDS-PAGE broad range molecular weight markers (M1) and Amersham ECL protein molecular weight markers (M2). (B) The humoral immune profile at 0 , 30,60 , and $90 \mathrm{~d}$ post challenge, and $10 \mathrm{~d}$ post treatment (PT) with dexamethasone (DEX, $0.55 \mathrm{mg} \mathrm{kg}^{-1}$ body weight) from 2 CCV/DEX-treated fish (lanes 1 to 5 and 6 to 10) representing positive samples and from 1 mock/DEX-treated fish (lanes 11 to 15$)$ representing a negative sample in western blots. Positive (+) and negative (-) fish serum controls; $\mathrm{M}=$ ECL protein molecular weight markers (Amersham). No bands were detected with these samples in blots on mock-infected BB cell lysates (patterns were identical to negative fish serum control) 


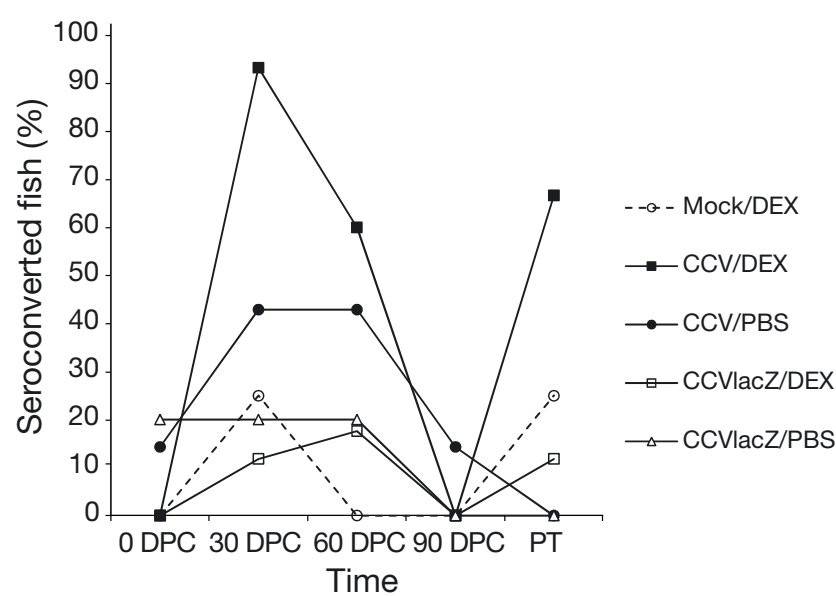

Fig. 3. Ictalurus punctatus. Percentage of fish testing positive for channel catfish virus (CCV) specific antibodies using western blots. Serum samples were obtained from fish exposed to no virus (mock), CCV, or the thymidine kinase-negative recombinant CCVlacZ, on different d post challenge (DPC) and following attempted reactivation treatment with dexamethasone (DEX, $0.55 \mathrm{mg} \mathrm{kg}^{-1}$ body weight) or phosphatebuffered saline (PBS; control) at $90 \mathrm{DPC}(\mathrm{PT}=$ average of 2, 4, 7 , and $10 \mathrm{~d}$ post treatment samples). Sample sizes: Mock/ $\mathrm{DEX}=4 ; \mathrm{CCV} / \mathrm{DEX}=15 ; \mathrm{CCV} / \mathrm{PBS}=7 ; \mathrm{CCVlacZ} / \mathrm{DEX}=17$; CCVlacZ/PBS $=5$

challenge. Their western blots showed reactivity against viral proteins ranging in size from $\sim 35$ to $68 \mathrm{kDa}$. Immunogenicity against a $46 \mathrm{kDa}$ viral protein was observed at 30 DPC in 1 mock-infected fish (16D), but no induction of a secondary response was observed $2 \mathrm{~d}$ post DEX treatment. In contrast, the reactivity to a CCV antigen $(\sim 139 \mathrm{kDa})$ was evident after administration of DEX to another mock-infected fish (16A) without prior seroreactivity to CCV (Table 2). Western blots from 9 CCVlacZ- (24.3\%) and 15 CCV-exposed (57.6\%) fish had antibodies that recognized cellular proteins present in mockinfected cell lysates. These cell-reactive antibodies recognized low molecular mass proteins with apparent masses ranging from 20 to $68 \mathrm{kDa}$. Fig. 4 illustrates the presence of cell-reactive antibodies in a western blot from a CCV-infected fish.

\section{Evaluation of serum neutralizing activity}

A serum neutralization test was performed with a subgroup of 29 fish representing 5 treatment groups: mock/DEX $(\mathrm{N}=4), \mathrm{CCV} / \mathrm{DEX}(\mathrm{N}=7), \mathrm{CCVlacZ} / \mathrm{DEX}$ $(\mathrm{N}=6), \mathrm{CCV} / \mathrm{PBS}(\mathrm{N}=6)$, and CCVlacZ/PBS $(\mathrm{N}=6)$. Fish with SNI values $>1$ were considered positive for neutralizing activity. The SNI measured at 60 DPC identified 8 (62\%) CCV- and 3 (25\%) CCVlacZexposed fish as positive (Table 3 ). In these positive fish, the SNI values ranged from 1.12 to 3.95 and 1.28 to 2.37 in the CCV- and CCVlacZ-exposed groups, respectively. Comparing SNI to western blot data by Spearman's correlation demonstrated a significant relationship ( $\mathrm{p}<0.01)$ with a rho value of 0.582 . The mean \pm SD SNI was $0.53 \pm 0.65(\mathrm{~N}=38)$ and $1.75 \pm 1.00$ $(\mathrm{N}=20)$ for western blot negative and western blot positive samples respectively and they were significantly different $(p<0.001)$. Of the 38 western blot negative samples (29 at $60 \mathrm{~d}$ and the same samples after treatment), 8 had SNI above 1.0. Of these, 3 samples had SNI above the $95 \%$ CI for the mean for that group. Of the 20 western blot positive samples, 4 had SNI below 1.0. The greatest number of fish identified as positive, following a stimulus to reactivate virus, were among those sampled at 2 DPT. The SNI values measured in serum samples from $4 \mathrm{CCV} / \mathrm{DEX}$ treated fish ranged from 1.54 to 3.11 whereas $4 \mathrm{CCV} / \mathrm{PBS}$-treated fish had SNI values ranging from 1.12 to 2.93. In contrast, only 1 CCVlacZ/DEX-treated fish was considered positive with an SNI value no greater than 1.2. None of the serum samples from the mock-infected group had detectable levels of neutralizing activity. Overall, SNI values significantly differed between treatments $(F=7.46, \mathrm{df}=4,28, \mathrm{p}=0.025)$. Regardless of the treatment, fish exposed to $\mathrm{CCV}$ had the highest SNI values (Fig. 5). The SNI values from serum samples obtained post DEX treatment were not significantly different from PBS-injected controls $(F=2.58$, $\mathrm{df}=5,11, \mathrm{p}=0.317$ ).

\section{Evaluation of the pattern of CCV gene expression}

To evaluate CCV gene expression in latently infected fish, we used RT-PCR to determine if the regions of representative immediate early (ORF 3 and ORF 12), early (ORF 57) and late (ORF 46) genes were transcribed. In cell culture, transcripts representing all regions were detected at 1 and $3 \mathrm{~h}$ post infection, and all except ORF 12 were blocked by cycloheximide exposure when sampled at $2 \mathrm{~h}$ post infection (Fig. 6). This experiment was repeated twice with the same outcome. No product was seen when reverse transcriptase was omitted from the reaction mix.

\section{CCV gene expression during latency and following dexamethasone treatment}

To elucidate the events occurring during the establishment of latency by CCV and CCVlacZ, as well as immediately after administration of DEX, we examined viral gene expression in PBL and caudal fin 
Table 2. Molecular mass (kDa) of viral protein subunits recognized by channel catfish virus (CCV)-specific antibodies in channel catfish. Fish were analyzed by western blotting on different days post challenge with CCV or the thymidine kinase-negative recombinant CCVlacZ and following attempted reactivation treatment with dexamethasone (DEX, $0.55 \mathrm{mg} \mathrm{kg}^{-1}$ body weight) or phosphatebuffered saline (PBS; control) at $90 \mathrm{~d}$ post challenge (DPC). DPT $=2,4,7$, and $10 \mathrm{~d}$ post treatment. $\mathrm{N}=$ negative, $\mathrm{ND}=$ not done, Mock $=$ mock-treated

\begin{tabular}{|c|c|c|c|c|c|}
\hline $\begin{array}{l}\text { Treatment } \\
\text { and fish no. }\end{array}$ & 0 DPC & 30 DPC & $\begin{array}{c}\text { Time } \\
60 \mathrm{DPC}\end{array}$ & 90 DPC & DPT \\
\hline \multicolumn{6}{|l|}{ Mock/DEX } \\
\hline $16 \mathrm{~A}$ & $\mathrm{~N}$ & $\mathrm{~N}$ & $\mathrm{~N}$ & $\mathrm{~N}$ & 139 \\
\hline $16 \mathrm{D}$ & $\mathrm{N}$ & 46 & ND & ND & $\mathrm{N}$ \\
\hline \multicolumn{6}{|l|}{ CCV/DEX } \\
\hline $13 \mathrm{~A}$ & $\mathrm{~N}$ & $40,90,139,>200$ & $90,>200$ & $\mathrm{~N}$ & 90 \\
\hline $13 \mathrm{D}$ & $\mathrm{N}$ & $31,>200$ & $31,>200$ & $\mathrm{~N}$ & 31,200 \\
\hline $13 \mathrm{E}$ & $\mathrm{N}$ & $20,55,139,>200$ & $20,139,>200$ & $\mathrm{~N}$ & $20,139,200$ \\
\hline $14 \mathrm{~A}$ & $\mathrm{~N}$ & $40,90,139,>200$ & 40,139 & $\mathrm{~N}$ & $139,>200$ \\
\hline $14 \mathrm{C}$ & $\mathrm{N}$ & $20,31,139$ & $\mathrm{~N}$ & $\mathrm{~N}$ & 55,90 \\
\hline $14 \mathrm{D}$ & $\mathrm{N}$ & $40,90,97,121,139$ & $20,40,90,139$ & $\mathrm{~N}$ & $20,55,121,139$ \\
\hline $14 \mathrm{E}$ & $\mathrm{N}$ & $40,90,97,139$ & $90,97,139$ & $\mathrm{~N}$ & 90,139 \\
\hline $19 \mathrm{C}$ & $\mathrm{N}$ & $139,>200$ & $\mathrm{~N}$ & $\mathrm{~N}$ & 139 \\
\hline $19 \mathrm{D}$ & $\mathrm{N}$ & 90 & $\mathrm{~N}$ & $\mathrm{~N}$ & $\mathrm{~N}$ \\
\hline $19 \mathrm{E}$ & $\mathrm{N}$ & $35,139,>200$ & 35,139 & $\mathrm{~N}$ & 35,139 \\
\hline $20 \mathrm{~A}$ & $\mathrm{~N}$ & 40 & $\mathrm{~N}$ & $\mathrm{~N}$ & $\mathrm{~N}$ \\
\hline $20 \mathrm{C}$ & $\mathrm{N}$ & 90 & 90 & $\mathrm{~N}$ & $\mathrm{~N}$ \\
\hline $21 \mathrm{C}$ & $\mathrm{N}$ & $46,121,139$ & $\mathrm{~N}$ & $\mathrm{~N}$ & $\mathrm{~N}$ \\
\hline $21 \mathrm{E}$ & $\mathrm{N}$ & $68,90,97,139$ & $68,90,97,139$ & $\mathrm{~N}$ & $90,97,139$ \\
\hline \multicolumn{6}{|l|}{ CCVlacZ/DEX } \\
\hline $2 B$ & $\mathrm{~N}$ & $\mathrm{~N}$ & $\mathrm{~N}$ & $\mathrm{~N}$ & 55 \\
\hline $6 \mathrm{~B}$ & $\mathrm{~N}$ & $20,90,139$ & 90 & $\mathrm{~N}$ & $>200$ \\
\hline $8 B$ & $\mathrm{~N}$ & 139 & 139 & $\mathrm{~N}$ & 139 \\
\hline $10 \mathrm{~B}$ & $\mathrm{~N}$ & $\mathrm{~N}$ & 20 & $\mathrm{~N}$ & $\mathrm{~N}$ \\
\hline \multicolumn{6}{|l|}{$\mathrm{CCV} / \mathrm{PBS}$} \\
\hline $15 \mathrm{~A}$ & $\mathrm{~N}$ & 68,139 & 68 & $\mathrm{~N}$ & $\mathrm{~N}$ \\
\hline $15 B$ & $\mathrm{~N}$ & $40,68,90$ & 40,90 & $\mathrm{~N}$ & $\mathrm{~N}$ \\
\hline $18 \mathrm{E}$ & 68 & $\mathrm{~N}$ & $\mathrm{~N}$ & $\mathrm{~N}$ & $\mathrm{~N}$ \\
\hline $22 \mathrm{D}$ & $\mathrm{N}$ & $\mathrm{N}$ & $68,90,139$ & 46 & $\mathrm{~N}$ \\
\hline $22 \mathrm{E}$ & $\mathrm{N}$ & $31,35,139,>200$ & $\mathrm{~N}$ & $\mathrm{~N}$ & $\mathrm{~N}$ \\
\hline \multicolumn{6}{|l|}{ CCVlacZ/PBS } \\
\hline $3 \mathrm{C}$ & 35 & 35 & 35 & $\mathrm{~N}$ & $\mathrm{~N}$ \\
\hline
\end{tabular}

Table 3. Comparison of western blot and neutralizing antibody data in channel catfish serum samples. Samples were taken at $60 \mathrm{~d}$ post challenge (DPC) with no virus (mock), channel catfish virus (CCV), or thymidine kinase-negative recombinant CCV (CCVlacZ), and after attempted reactivation treatment with dexamethasone (DEX, $0.55 \mathrm{mg} \mathrm{kg}^{-1}$ body weight) or phosphate-buffered saline (PBS; control) at 90 DPC. Post $=2,4,7$, and $10 \mathrm{~d}$ post treatment

\begin{tabular}{|lccccccc|}
\hline \multirow{2}{*}{ Treatment } & \multirow{2}{*}{$\begin{array}{l}\text { Western blot } \\
\text { Positive (total) }\end{array}$} & \multicolumn{4}{c|}{ Serum neutralization index } \\
& 60 DPC & Post & 60 DPC & Post & 60 DPC & Post \\
\hline Mock/DEX & $0(3)$ & $1(4)$ & $0(4)$ & $0(4)$ & $0.35 \pm 0.40$ & $0.37 \pm 0.27$ \\
CCV/DEX & $5(7)$ & $6(7)$ & $4(7)$ & $5(7)$ & $1.36 \pm 1.10$ & $1.60 \pm 0.90$ \\
CCVlacZ/DEX & $3(6)$ & $2(6)$ & $3(6)$ & $2(6)$ & $0.99 \pm 1.05$ & $0.42 \pm 0.51$ \\
CCV/PBS & $3(6)$ & $0(6)$ & $4(6)$ & $4(6)$ & $1.78 \pm 1.57$ & $1.40 \pm 1.13$ \\
CCVlacZ/PBS & $2(6)$ & $0(6)$ & $0(6)$ & $1(6)$ & $0.31 \pm 0.21$ & $0.62 \pm 0.40$ \\
& & & & & & & \\
\hline
\end{tabular}

samples by RT-PCR. The ORF 3 gene RT-PCR products were detected by slot-blot hybridization due to the presence of 2 bands in polyacrylamide gels, one of which may represent a non-specific amplification product (Fig. 6). Table 4 summarizes the mRNA expression of the ORF 3, ORF 12, ORF 57 and ORF 46 regions. Out of $10 \mathrm{CCV}$ - and 10 CCVlacZexposed fish, we detected only 2 fish that were expressing ORF 3-containing transcripts (18A and 22D) by 90 DPC. Both were CCV exposed. Following treatment to induce reactivation, ORF 3-containing transcripts were detected in 1 CCV/DEX- (19E), $2 \mathrm{CCV} / \mathrm{PBS}-$ (18A and 22E), and 1 CCVlacZ/DEX-treated fish (6C). Expression of ORF 12 was detected in $3 \mathrm{CCV}-(13 \mathrm{D}, 18 \mathrm{E}$ and $20 \mathrm{~A})$ and 4 CCVlacZ-exposed fish (3A, 6C, $7 \mathrm{~A}$ and 10B) by 90 DPC. Following a stimulus to induce reactivation, samples from 1 CCV/DEX- (13D), 1 CCV/PBS- (22D), 1 CCVlacZ/DEX(6C) and 2 CCVlacZ/PBS-treated fish (7A and 7D) were positive for ORF 12 expression. Expression of ORF 57 and ORF 46 was rarely detected. On 2 occasions, ORF 57-containing transcripts were present: in the sample from a CCVlacZ-challenged fish (6B) at 90 DPC and in the sample from a CCV/PBS-treated fish (22D) after treatment. Detection of late gene expression by ORF 46 was limited to a single CCV/PBS-treated fish (22E). Concurrent expression of genes was detected in 3 fish post treatment: ORF 3- and ORF 46-containing transcripts were detected in fish 22E (CCV/PBS); ORF 12- and ORF 57containing transcripts were detected in fish 22D (CCV/PBS); and ORF 3-and ORF 12-containing transcripts were detected in fish 6C (CCVlacZ/ DEX). Serial expression profiles (where expression of at least 1 gene region was detected in the same fish at 90 DPC and after treatment) were seen in 5 fish: 1 CCV/DEX (13D), $2 \mathrm{CCV} / \mathrm{PBS}$ (18A and 22D), 1 CCVlacZ/DEX (6C) and 1 CCVlacZ/ PBS (7A). 


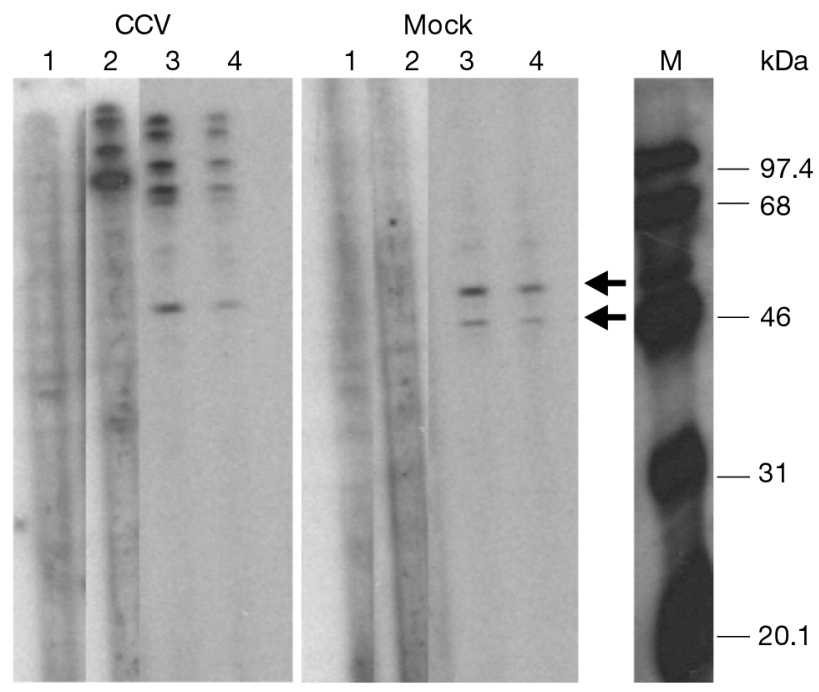

Fig. 4. Cell-reactive antibodies detected in serum samples from channel catfish with a latent channel catfish virus (CCV) infection using western blots. Mock- and CCV-infected brown bullhead cell lysates were separated by $12 \%$ SDSPAGE and blotted onto nitrocellulose membranes. Negative (Lane 1) and positive (Lane 2) fish serum controls diluted 1:25; latently CCV-infected fish serum diluted 1:25 (Lane 3) and 1:50 (Lane 4); $\mathrm{M}=\mathrm{ECL}$ protein molecular weight markers

(Amersham). Arrows indicate cellreactive antibodies

\section{DISCUSSION}

Our goals were to evaluate the immune response of channel catfish to CCV and CCVlacZ after the establishment of latency and to characterize viral recrudescence. In a previous study, channel catfish were

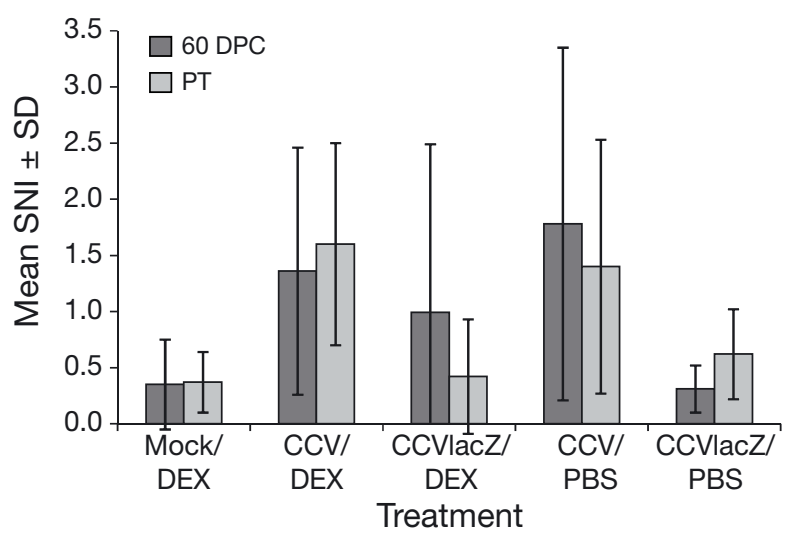

Fig. 5. Serum neutralizing activity in channel catfish $60 \mathrm{~d}$ post challenge (DPC) with no virus (mock), channel catfish virus $(\mathrm{CCV})$ or the thymidine kinase-negative recombinant CCVlacZ, and following attempted reactivation treatment with dexamethasone (DEX, $0.55 \mathrm{mg} \mathrm{kg}^{-1}$ body weight) or phosphate-buffered saline (PBS; control) at 90 DPC challenge. Mock/DEX $(\mathrm{N}=4) ;$ CCV/DEX $(\mathrm{N}=7) ;$ CCVlacZ/DEX $(\mathrm{N}=6)$; CCV/PBS $(\mathrm{N}=6) ;$ CCVlacZ/PBS $(\mathrm{N}=6)$. SNI = serum neutralizing index, $\mathrm{PT}=2,4,7$, or $10 \mathrm{~d}$ post treatment
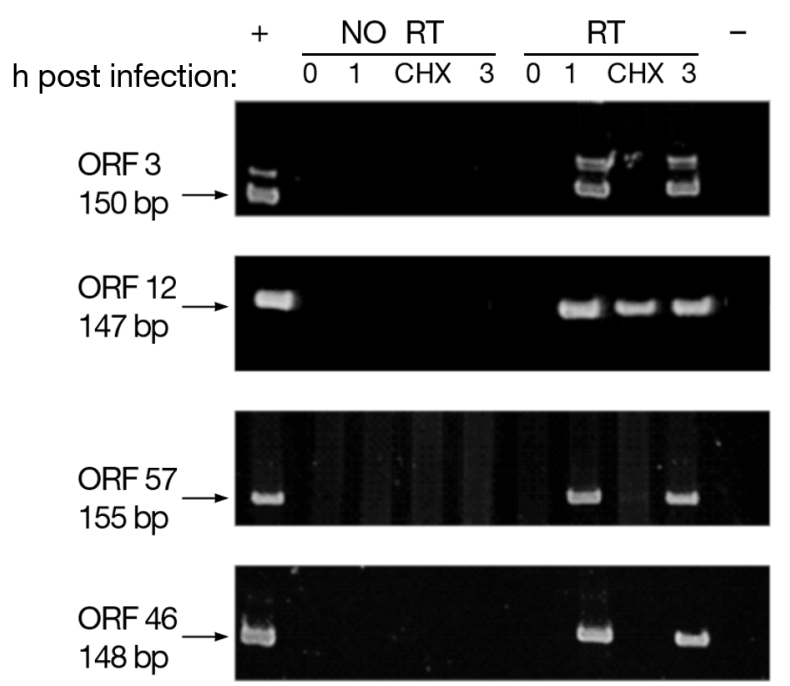

Fig. 6. Temporal expression of immediate-early (ORF 3 and ORF 12), early (ORF 57), and late (ORF 46) channel catfish virus (CCV) genes in channel catfish ovary cell cultures as detected by RT-PCR. Cell lysates were infected with 10 plaque-forming units CCV cell ${ }^{-1}$ and harvested at 0,1 , and $3 \mathrm{~h}$ post infection. Additional CCV-infected cell lysates were treated with $100 \mathrm{\mu g} \mathrm{ml}^{-1}$ cycloheximide (CHX) and harvested at $2 \mathrm{~h}$ post infection. RT-PCR products were analyzed by $10 \%$ acrylamide gel electrophoresis and GelStar staining. $\mathrm{RT}=$ reverse transcriptase; NO RT $=$ without $\mathrm{RT}_{;}+$: positive control using purified CCV DNA; -: negative control using water

infected with similar doses of CCV or a TK-negative mutant and demonstrated that $100 \%$ of 16 sampled fish developed disseminated viremia by $4 \mathrm{~d}$ post infection and this progressed to latent infections in the survivors (as defined by presence of detectable CCV genome but no infectious virus) by $12 \mathrm{~d}$ post exposure (Kancharla \& Hanson 1996). However, the authors did not attempt to induce recrudescence or evaluate the immune response over time. We were unable to induce productive recrudescence with either strain, but gene expression data and the long-term immunological profile of channel catfish after exposure to CCV or CCVlacZ and following DEX treatment suggest partial recrudescence. Data from western blot analyses showed that CCV-specific antibodies were predominantly directed against high molecular mass proteins ranging from $\sim 90$ to $>200 \mathrm{kDa}$. The antibody reactivity against $\mathrm{CCV}$ antigens varied over time and declined markedly around 90 DPC in most seropositive fish.

More fish exposed to CCV produced detectable CCV-specific antibodies and these antibodies recognized a broader spectrum of viral proteins compared to those produced by fish exposed to CCVlacZ. Likewise, fish exposed to CCV had higher neutralizing antibody activity than those exposed to CCVlacZ. Previous studies found that the ability of the TK-deleted recombinants to infect and replicate early during the infection 
Table 4. Ictalurus punctatus. No. of channel catfish that expressed channel catfish virus (CCV) genes $90 \mathrm{~d}$ post challenge (DPC) with CCV or thymidine kinase-negative recombinant CCV (CCVlacZ), and following treatment with dexamethasone (DEX, $0.55 \mathrm{mg} \mathrm{kg}^{-1}$ body weight) or phosphate-buffered saline (PBS; control) at 90 DPC. ORF 12, ORF 57, and ORF 46 were detected by RTPCR, while ORF 3 was detected by slot blot hybridization of the RT-PCR product. Post $=2,4,7$, and $10 \mathrm{~d}$ post treatment. $\mathrm{N}=5$ fish per treatment

\begin{tabular}{|lcccccccc|}
\hline Treatment & $\begin{array}{c}\text { ORF } 3 \\
\text { 90 DPC Post }\end{array}$ & $\begin{array}{c}\text { ORF 12 } \\
\text { 90 DPC Post }\end{array}$ & $\begin{array}{c}\text { ORF 57 } \\
\text { 90 DPC Post }\end{array}$ & $\begin{array}{c}\text { ORF 46 } \\
\text { 90 DPC Post }\end{array}$ \\
\hline CCV/DEX & 0 & 1 & 2 & 1 & 0 & 0 & 0 & 0 \\
CCV/PBS & 2 & 2 & 1 & 1 & 0 & 1 & 0 & 1 \\
CCVlacZ/DEX & 0 & 1 & 2 & 1 & 1 & 0 & 0 & 0 \\
CCVlacZ/PBS & 0 & 0 & 2 & 2 & 0 & 0 & 0 & 0 \\
\hline
\end{tabular}

induces apoptosis in nonspecific cytotoxic cells, and has immunosuppressive properties (Rousseau \& Baxter 1979, Yamamoto 1985, Bishop et al. 2000). Glucocorticoids are the gold standard agents for anti-inflammatory and immunomodulatory therapy, whose main mechanism of action relies on inhibiting the activity of transcription factors, such as nuclear factor-kappa B $(\mathrm{NF}-\kappa \mathrm{B})$ and activator protein-1 (AP-1) (De Bosscher et al. 2000). Therefore, a secondary antibody response is unexpected. However, glucocorticoids often induce reac-

was similar to the parent CCV, but then virus numbers dwindled more quickly (Zhang \& Hanson 1995, Kancharla \& Hanson 1996). This more rapid clearance may account for a lesser stimulation of specific antibody responses that we observed in the western blots.

Even though there was a good correlation between neutralizing antibody assays and western blot data, there were several cases where western blot negative fish had positive SNI and vice versa. This result is not unexpected since serum neutralization is often based on antibodies binding secondary or tertiary structural epitopes on the virus anti-receptor, whereas the SDSPAGE treatment in western blot assays necessitates the evaluation of antibodies that mainly recognize primary structures. Furthermore, western blot assays evaluate responses to many more proteins in addition to those involved in the infection process. Similar results were documented by Crawford et al. (1999). After experimental CCV exposure, they found that many fish had a negative SNI but were seropositive for CCV antigens when evaluated by ELISA. Also, they found that a similar percentage of fish (65\%) seroconverted by 5 wk post exposure to a similar concentration of CCV as was used in our study.

The secondary induction of an antibody response was only demonstrated in fish that received DEX treatment. Serum samples from these fish demonstrated recognition of at least 1 viral protein with molecular mass similar to that recognized after the primary infection. No secondary immune response was observed in any fish injected with PBS alone for either CCV or CCVlacZ. Although these results imply that a recrudescent expression of CCV proteins was occurring, the attempted reactivation using DEX injection did not result in production of infectious virus in co-cultivation cultures from any PBL sample or tissue homogenates of the fish.

The injection of DEX resulted in elevated virusspecific antibodies. DEX is a synthetic glucocorticoid that regulates cellular and viral gene expression, tivation of herpesviruses from latency. DEX treatment is a reliable method for reactivation of suid herpesvirus 1 , equid herpesvirus 1 , and caprine herpesvirus 1 when administrated alone (Gibson et al. 1992, Mengeling et al. 1992, Buonavoglia et al. 1996). The single DEX application likely induced sufficient CCV recrudescence to stimulate a secondary immune response and this response quickly suppressed virus production and prevented us from being able to culture the virus. Others have demonstrated an immune response to reactivated virus after DEX treatment. Tanaka \& Mannen (2002) showed the activation of latent suid herpesvirus 1 in mice after DEX or acetylcholine treatment resulted in viral excretion and increased antibody titers. An alternative explanation is that the DEX treatment influenced antibody levels non-specifically. There are a few unusual cases where DEX has been shown to cause higher serum antibodies. In one case, a low dose of corticosteroid given orally to an immunodeficient patient with splenomegaly reduced the hypercatabolism of immunoglobulin by macrophages and this allowed administered immunoglobulin to build up in the blood (Spickett et al. 1996). Another possibility could be that the dosage of DEX administered in our study disrupted the activity of regulatory $\mathrm{T}$ lymphocytes $\left(\mathrm{T}_{\text {reg }}\right.$ ) or dendritic cells, allowing suppressed B-lymphocytes to generate antibodies. However, this possibility is unlikely. $\mathrm{T}_{\text {reg }}$ and dendritic cells are poorly characterized in fish, but in mammals DEX stimulates suppressive pathways in dendritic cells (Grohmann et al. 2007) and enhances the activity and numbers of $\mathrm{T}_{\text {reg }}$ cells (Karagiannidis et al. 2004).

Contrary to results reported by Bowser et al. (1985), we did not isolate infectious virus in co-cultivation assays in the initial trial with carrier fish and in the second trial with experimentally infected fish. Reactivation of herpesviruses is a complex phenomenon. Immunity plays an important role in modifying the outcome of primary and recurrent herpes simplex virus infections (Nash \& Wildly 1983). In humans, 
reactivation of HSV-1 is often influenced by immunity characterized by no detectable rise in circulating neutralizing antibodies (Douglas \& Couch 1970). Simmons \& Nash (1985) reported that the zosteriform spread of HSV-1 was completely inhibited by neutralizing antibodies. In a study on recrudescence of gammaherpesviruses in immunocompromized hosts, those that had antibodies to a lytic cycle viral protein were able to control virus re-expression (Gangappa et al. 2002). Furthermore, reactivation of herpesviruses in mammals sometimes requires administration of DEX in conjunction with cyclophosphamide (Minagawa et al. 1994) or anti-serum to lymphocytes to suppress antibody production (Bevan et al. 1996). We evaluated 2 potential methods of inducing recrudescence, heat stress and DEX injection, and their effect in combination. The heat stress response is characterized by the induction of heat shock proteins (HSPs) when cells are exposed to elevated temperatures. Stress-inducible HSPs, such as Hsp72, have anti-inflammatory properties. Tang et al. (2007) demonstrated an inhibition of NF- $\kappa \mathrm{B}$ activity in cells expressing abundant Hsp72. This inhibition in turn decreased cellular levels of high-mobility-group box 1 induced cytokines (tumor necrosis factor [TNF]- $\alpha$ and interleukin [IL]-1 $\beta$ ) and proinflammatory signaling in macrophages. Heat was evaluated here because heat exposure has been shown to induce HSV-1 in mammals (Sawtell \& Thompson 1992, 2004). Moreover, Halford et al. (1996) postulated that pre-treatment of cultures with DEX facilitated the induction of HSV-1 lytic-phase mRNA transcription following heat stress. Furthermore, natural outbreaks of CCVD occur primarily during elevated summertime temperatures. We chose the dose of DEX based on the findings of Bowser et al. (1985). Contrary to what was expected, administration of DEX in our study did not result in productive infection in latently infected catfish. However, the PCR detection rate of CCV DNA increased from 40 to $100 \%$, and this increase was not observed in any other treatments. There are 2 other studies where the researchers failed to isolate CCV from tissues of adult channel catfish suspected of carrying the virus after chemical or corticosteroid induction (Huston 1979, Plumb et al. 1981). The major difference between the findings of Bowser et al. (1985) and ours may relate to the physiology of the fish. In the study by Bowser et al. (1985), moribund, naturally infected CCV carriers were injected with DEX. These fish were adult broodfish, housed in outdoor ponds and exposed to winter conditions. Low temperature suppresses cellular and humoral immunity in channel catfish (Plumb et al. 1986, Bly \& Clem 1991). A natural immunosuppressed state combined with the effect of the DEX may be needed to provide the level of recrudescence neces- sary to detect the virus in cell cultures. In future studies on CCV recrudescence, we plan to expose fish to low water temperatures and to decrease intervals of sample collection by adding time points at 6 and $12 \mathrm{~h}$ post DEX treatment.

The sporadic nature of expression of the selected gene regions precludes broad conclusions about gene expression profiles during latency according to expression class. However, in these analyses we looked at virus-exposed fish at 2 time points (90 DPC and post treatment) and we did detect virus gene transcription at one or both of these time points in 7 out of $10 \mathrm{CCV}$ exposed fish and in 6 out of 10 CCVlacZ-exposed fish. This suggests that sporadic CCV gene expression is relatively common in latently infected fish. Furthermore, serial expression was documented in 5 of these 13 fish. These findings indirectly support the suggestion that protein expression may induce increased antibody levels after DEX exposure.

Although not the focus of this research, we found a high incidence of antibodies reacting to proteins in mock-infected cell lysates in serum samples from channel catfish exposed to either CCV or CCVlacZ. The etiology of many chronic autoimmune diseases is still uncertain, but infectious agents have often been implicated in their pathogenesis. Cell-reactive antibodies have been reported in patients suffering from autoimmune diseases that in some cases also have specific antibodies to chronic herpesvirus infections including Epstein-Barr virus, human herpesvirus type 6, human cytomegalovirus, and herpes simplex virus (Vaughan et al. 1996, Galanakis et al. 2001, Nawata et al. 2001, Simmons 2001, Totani et al. 2001, Zhang et al. 2001, Alvarez-Lafuente et al. 2002).

The combined results obtained from western blot, SNI, and RT-PCR data suggest some viral recrudescence in channel catfish that received DEX treatment. This study illustrates the recalcitrant nature of CCV latency and suggests that recrudescence is rare and tightly regulated. Evaluating the extent and the physiological impact of virus reactivation on latently infected carriers will require a better understanding of the factors that restrain latent $\mathrm{CCV}$ from undergoing productive replication. Further investigation is necessary to examine the expression of CCV genes and to characterize the cell types involved during the latent and recrudescent phases of infection.

Acknowledgements. The authors thank B. Griffin (Harry K. Dupree Stuttgart National Aquaculture Research Center, US Department of Agriculture, Agricultural Research Center, Stuttgart, Arkansas) for the gift of specific pathogen-free channel catfish juveniles used in this experiment; M. R. Rudis for her technical assistance; F. J. Vilella (Mississippi Cooperative Fish and Wildlife Research Unit) for statistical counseling and C. Boyle for assistance with statistical analysis. 


\section{LITERATURE CITED}

Alvarez-Lafuente R, Martin-Estefania C, de las Heras V, Castrillo $\mathrm{C}$ and others (2002) Prevalence of herpesvirus DNA in multiple sclerosis patients and healthy blood donors. Acta Neurol Scand 105:95-99

Baxi MK, Borchers K, Bartels T, Schelllenbach A, Baxi S, Field HJ (1996) Molecular studies of the acute infection, latency and reactivation of equine herpesvirus-1 (EHV-1) in the mouse model. Virus Res 40:33-45

Bevan IS, Sammons CC, Sweet C (1996) Investigation of murine cytomegalovirus latency and reactivation in mice using viral mutants and the polymerase chain reaction. J Med Virol 48:308-320

Bishop GR, Jaso-Friedman L, Evans DL (2000) Activationinduced programmed cell death of nonspecific cytotoxic cells and inhibition by apoptosis regulatory factors. Cell Immunol 199:126-137

Bly JE, Clem LW (1991) Temperature-mediated processes in teleost immunity: in vitro immunosuppression induced by in vivo low temperature in channel catfish. Vet Immunol Immunopathol 28:365-377

> Bowser PR, Munson AD, Jarboe HH, Francis-Floyd R, Waterstrat PR (1985) Isolation of channel catfish virus from channel catfish, Ictalurus punctatus (Rafinesque), broodstock. J Fish Dis 8:557-561

Buck CD, Loh PC (1985) Liquid overlay plaquing of channel catfish virus. J Fish Dis 8:325-328

Buonavoglia C, Tempesta M, Cavalli A, Voigt V, Buonavoglia D, Conserva A, Corrente M (1996) Reactivation of caprine herpesvirus 1 in latently infected goats. Comp Immunol Microbiol Infect Dis 19:275-281

Burnette WN (1981) Western blotting: electrophoretic transfer of proteins from sodium dodecyl sulfate-polyacrylamide gels to unmodified nitrocellulose and radiographic detection with antibody and radioiodinated protein. Anal Biochem 112:195-203

> Chen H, Walbieser GC, Rice CD, Elibol B, Wolters WR, Hanson LA (2002) Isolation and characterization of channel catfish natural resistance associated macrophage protein gene. Dev Comp Immunol 26:517-531

Chousterman S, LaCasa M, Sheldrick P (1979) Physical map of the channel catfish virus genome: location of sites for restriction endonucleases EcoRI, HindIII, HpaI, and XbaI. J Virol 31:73-85

> Crawford SA, Gardner IA, Hedrick RP (1999) An enzymelinked immunosorbent assay (ELISA) for detection of antibodies to channel catfish virus (CCV) in channel catfish. J Aquat Anim Health 11:148-153

> Davison AJ (1992) Channel catfish virus: a new type of herpesvirus. Virology 186:9-14

$>$ Davison AJ, Eberle R, Ehlers B, Hayward GS and others (2009) The order Herpesvirales. Arch Virol 154:171-177

> De Bosscher K, Berghe WV, Haegeman G (2000) Mechanisms of anti-inflammatory action and of immunosuppression by glucocorticoids: negative interference of activated glucocorticoid receptor with transcription factors. J Neuroimmunol 109:16-22

> Dixon RAF, Farber FE (1980) Channel catfish virus: physicochemical properties of the viral genome and identification of viral polypeptides. Virology 103:267-278

> Douglas RG, Couch RB (1970) A prospective study of chronic herpes simplex virus infection and recurrent herpes labialis in humans. J Immunol 104:289-295

Efstathiou S, Kemp S, Darby G, Minson AC (1989) The role of herpes simplex virus type 1 thymidine kinase in pathogenesis. J Gen Virol 70:869-879
Field HJ, Wildy P (1978) The pathogenicity of thymidine kinase-deficient mutants of herpes simplex virus in mice. J Hyg (Lond) 81:267-277

Fijan NN (1968) Progress report on acute mortality of channel catfish fingerlings by a virus. Bull Off Int Epizoot 69: 1167-1168

Fijan NN, Welborn TLJ, Naftel JP (1970) An acute viral disease of channel catfish. Technical Paper 43. US Fish and Wildlife Service, Washington, DC

Galanakis E, Bikouvarakis S, Mamoulakis D, Karampekios S, Sbyrakis S (2001) Transverse myelitis associated with herpes simplex virus infection. J Child Neurol 16:866-867

> Gangappa S, Kapadia SB, Speck SH, Virgin HW IV (2002) Antibody to a lytic cycle viral protein decreases gammaherpesvirus latency in B-cell-deficient mice. J Virol 76: 11460-11468

Gibson JS, O'Neill T, Thackray A, Hannant D, Field HJ (1992) Serological responses of specific pathogen-free foals to equine herpesvirus-1: primary and secondary infection and reactivation. Vet Microbiol 32:199-214

Gray WL, Williams RJ, Jordan RL, Griffin BR (1999) Detection of channel catfish virus DNA in latently infected catfish. J Gen Virol 80:1817-1822

Grohmann U, Volpi C, Fallarino F, Bozza S and others (2007) Reverse signaling through GITR ligand enables dexamethasone to activate IDO in allergy. Nat Med 13:579-586

Halford WP, Gebhardt BM, Carr DJJ (1996) Mechanisms of herpes simplex virus type 1 reactivation. J Virol 70: 5051-5060

Hanson LA, Thune RL (1993) Characterization of thymidine kinase encoded by channel catfish virus. J Aquat Anim Health 5:199-204

Hanson LA, Kousoulas KG, Thune RL (1994) Channel catfish herpesvirus (CCV) encodes a functional thymidine kinase gene: elucidation of a point mutation that confers resistance to Ara-T. Virology 202:659-664

- Hanson LA, Rudis MR, Petrie-Hanson L (2004) Susceptibility of channel catfish fry to channel catfish virus (CCV) challenge increases with age. Dis Aquat Org 62:27-34

Honess RW, Roizman B (1974) Regulation of herpesvirus macromolecular synthesis. I. Cascade regulation of the synthesis of three groups of viral proteins. J Virol 14:8-19

Huston MM (1979) Channel catfish virus disease: detection of latent virus and correlation with serology. $\mathrm{PhD}$ dissertation, Texas A\&M University, College Station

Jamieson AT, Gentry GA, Subak-Sharpe JH (1974) Induction of both thymidine and deoxycytidine kinase activity by herpes virus. J Gen Virol 24:465-480

Johnson DA, Gautsch JW, Sporstman JR, Elder JH (1984) Improved technique utilizing nonfat dry milk for analysis of proteins and nucleic acids transferred to nitrocellulose. Gene Anal Tech 1:3-8

Kancharla SR, Hanson LA (1996) Production and shedding of channel catfish virus (CCV) and thymidine kinase negative $\mathrm{CCV}$ in immersion exposed channel catfish fingerlings. Dis Aquat Org 27:25-34

> Karagiannidis C, Akdis M, Holopainen P, Woolley NJ and others (2004) Glucocorticoids upregulate FOXP3 expression and regulatory $\mathrm{T}$ cells in asthma. J Allergy Clin Immunol 114:1425-1433

> Laemmli UK (1970) Cleavage of structural proteins during the assembly of the head of bacteriophage T4. Nature 227: $680-685$

> Lobb CJ, Clem LW (1982) Fish lymphocytes differ in the expression of surface immunoglobulin. Dev Comp Immunol 6:473-479

Lobb CJ, Olson MOJ, Clem LW (1984) Immunoglobulin light 
chain classes in a teleost fish. J Immunol 132:1917-1923

Mengeling WL, Lager KM, Volz DM, Brockmeier SL (1992) Effect of various vaccination procedures on shedding, latency, and reactivation of attenuated and virulent pseudorabies virus in swine. Am J Vet Res 53:2164-2173

Minagawa H, Tanaka S, Toh Y, Mori R (1994) Detection of herpes simplex type 1-encoded RNA by polymerase chain reaction: different pattern of viral RNA detection in latently infected murine trigeminal ganglia following in vitro or in vivo reactivation. J Gen Virol 75:647-650

Nash AA, Wildly P (1983) Immunity in relation to the pathogenesis of herpes simplex virus. In: Ennis FA (ed) Human immunity to viruses. Academic Press, New York, NY, p 179-192

Nawata M, Seta N, Yamada M, Sekigawa I, Iida N, Hashimoto $\mathrm{H}$ (2001) Possible triggering effect of cytomegalovirus infection on systemic lupus erythematosus. Scand J Rheumatol 30:360-362

Plumb JA, Gaines JL (1975) Channel catfish virus disease. In: Ribelin WE, Migaki G (eds) The pathology of fishes. The University of Wisconsin Press, Madison, WI, p 287-302

Plumb JA, Thune RL, Klesius PH (1981) Detection of channel catfish virus in adult fish. Dev Biol Stand 49:29-34

Plumb JA, Wise ML, Rogers WA (1986) Modulary effects of temperature on antibody response and specific resistance to challenge of channel catfish, Ictalurus punctatus, immunized against Edwardsiella ictaluri. Vet Immunol Immunopathol 12:297-304

Reed LJ, Muench H (1938) A simple method of estimating fifty percent endpoints. Am J Hyg 27:493-497

Rousseau GG, Baxter JD (eds) (1979) Glucocorticoid hormone action. Springer Verlag, Heidelberg

SAS (1990) SAS/STAT Version 6 User's Guide. SAS Institute, Cary, NC

Sawtell NM, Thompson RL (1992) Rapid in vivo reactivation of herpes simplex virus in latently infected murine ganglionic neurons after transient hyperthermia. J Virol 66: 2150-2156

Sawtell NM, Thompson RL (2004) Comparison of herpes simplex virus reactivation in ganglia in vivo and in explants demonstrates quantitative and qualitative differences. J Virol 78:7784-7794

Simmons A (2001) Herpesvirus and multiple sclerosis. Herpes 8:60-63

Simmons A, Nash A (1985) Role of antibody in primary and recurrent herpes simplex virus infection. J Virol 53: 944-948

Spickett GP, Zhang JG, Green T, Shrimankar J (1996) Granulomatous disease in common variable immunodeficiency: effect on immunoglobulin replacement therapy and

Editorial responsibility: V. Gregory Chinchar,

Jackson, Mississippi, USA response to steroids and splenectomy. J Clin Pathol 49: 431-434

Steel RGD, Torrie JH (1980) Principles and procedures of statistics, 2nd edn. McGraw-Hill, New York, NY

Tanaka S, Mannen K (2002) Activation of latent pseudorabies virus infection in mice treated with acetylcholine. Exp Anim 51:407-409

Tang D, Kang R, Xiao W, Wang H, Calderwood SK, Xiao X (2007) The anti-inflammatory effects of heat shock protein 72 involve inhibition of high-mobility-group box 1 release and proinflammatory function in macrophages. J Immunol 179:1236-1244

Tenser RB, Dunstan ME (1979) Herpes simplex virus thymidine kinase expression in infection of the trigeminal ganglion. Virology 99:417-422

Thompson DJ, Khoo LH, Wise DJ, Hanson LA (2005) Evaluation of channel catfish virus latency on fingerling production farms in Mississippi. J Aquat Anim Health 17:211-215

Totani Y, Demura Y, Ameshima S, Miyamori I, Ishizaki T (2001) A case of lymphocytic interstitial pneumonia with Sjogren's syndrome and systemic lupus erythematosus in which herpes virus-6 infection was the suspected pathogen. Nihon Kokyuki Gakkai Zasshi 39:763-769

Towbin H, Staehelin T, Gordon J (1979) Electrophoretic transfer of proteins from polyacrylamide gels to nitrocellulose sheets: procedure and some applications. Proc Natl Acad Sci USA 76:4350-4354

Vaughan JH, Riise T, Rhodes GH, Nguyen MD, BarrettConnor E, Nyland H (1996) An Epstein-Barr virus-related cross reactive autoimmune response in multiple sclerosis in Norway. J Neuroimmunol 69:95-102

Wise JA, Boyle JA (1985) Detection of channel catfish virus in channel catfish, Ictalurus punctatus (Ratinesque): use of a nucleic acid probe. J Fish Dis 8:417-424

Wolf K, Darlington RD (1971) Channel catfish virus: a new herpesvirus of ictalurid fish. J Virol 8:525-533

Yamamoto KR (1985) Steroid receptor regulated transcription of specific genes and gene networks. Annu Rev Genet 19: 209-215

Zhang HG, Hanson LA (1995) Deletion of thymidine kinase gene attenuates channel catfish herpesvirus while maintaining infectivity. Virology 209:658-663

Zhang HG, Hanson LA (1996) Recombinant channel catfish virus (Ictalurid herpesvirus 1) can express foreign genes and induce antibody production against the gene product. J Fish Dis 19:121-128

> Zhang C, Shen K, He X (2001) Early diagnosis and monitoring of active human cytomegalovirus infection in children with systemic lupus erythematosus. Chin Med J (Engl) 114:1309-1312

Submitted: August 19, 2010; Accepted: February 24, 2011 Proofs received from author(s): June 7, 2011 